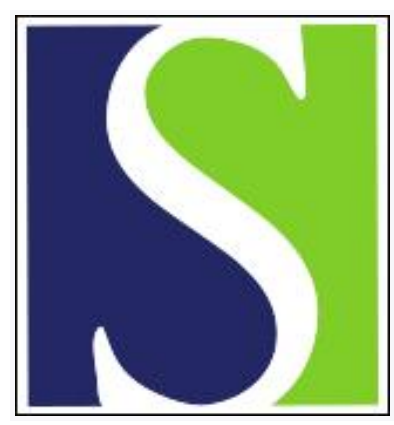

Scand J Work Environ Health 1978;4(1):66-72

https://doi.org/10.5271/sjweh.2727

Issue date: Mar 1978

Acute effects of tetraethyltiuram disulfide on serum levels of hypophyseal hormones in humans.

by Cavalleri A, Polatti F, Bolis PF

Key terms: acute effect; carbon disulfide; catecholamine metabolism; human; hypophyseal hormone; serum level; tetraethyltiuram disulfide; thyroid impairment

This article in PubMed: www.ncbi.nlm.nih.gov/pubmed/347565

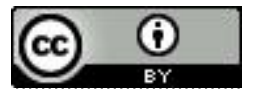




\title{
Acute effects of tetraethyltiuram disulfide on serum levels of hypophyseal hormones in humans
}

\author{
by ALESSANDRO CAVALLERI, M.D.,1 FRANCO POLATTI, M.D., ${ }^{2}$ \\ and PIER FRANCESCO BOLIS, M.D. ${ }^{2}$
}

\begin{abstract}
CAVALLERI, A., POLATTI, F. and BOLIS, P.F. Acute effects of tetraethyltiuram disulfide on serum levels of hypophyseal hormones in humans. Scand. $j$. work environ. \& health 4 (1978) 66-72. Tetraethyltiuram disulfide (TETD) is known to inhibit dopamine-beta-hydroxylase, a copper enzyme which catalyzes the transformation of dopamine into norepinephrine. For the determination of the effects of TETD, a compound with a biological action similar to that of carbon disulfide, nine male and seven female volunteers were given $1.0 \mathrm{~g}$ of the drug orally. Serum thyrotropin, prolactin, luteinizing hormone, and follicle-stimulating hormone were then assayed by radioimmunological methods before and $1,2,4$, and $24 \mathrm{~h}$ after the medication was administered. Immediately after the TETD administration, the serum thyrotropin level sharply decreased and reached the lowest point at the 24 th $h$. Prolactin appeared to decrease too, but it reached the initial level at the $24 \mathrm{th} \mathrm{h}$. A lower decrease was evidenced for the follicle-stimulating hormone, statistically significant only for males, and for the luteinizing hormone of females. Since dopamine has been proved to decrease the release of serum thyrotropin and prolactin and also since the secretion of the luteinizing and the follicle-stimulating hormone is regulated by monoamines of the central nervous system, the findings may be related to disturbances in catecholamine metabolism induced by TETD and carbon disulfide, and they may be explained by an increase in dopamine in the central nervous system and by the concomitant decrease of norepinephrine as a consequence of dopamine-beta-hydroxylase blockade. In addition these data may confirm the reduced thyroid activity found in workers exposed to carbon disulfide; the origin of the reduced activity seems related to a central involvement of catecholamine metabolism, which would influence the activity of target glands through hypothalamic releasing factors and the hypophyseal hormones.
\end{abstract}

Key words: carbon disulfide, catecholamine metabolism, hypophyseal hormones, thyroid impairment, tetraethyltiuram disulfide.

Chronic exposure to carbon disulfide $\left(\mathrm{CS}_{2}\right)$ has been demonstrated to impair adrenocortical and gonadal activity in man $(3,4$, $6,7,8,10,16)$. As an explanation for

1 Istituto di Medicina del Lavoro dell'Università di Pavia, Pavia, and Cattedra di Medicina del Lavoro dell'Università di Modena, Modena, Italy.

2 Clinica Ostetrica e Ginecologica dell'Università di Pavia, Pavia, Italy.

Reprint requests to: Prof. Alessandro Cavalleri, Istituto di Medicina del Lavoro dell'Università di Pavia, Via Boezio 24, 27100 Pavia, Italy. this finding a pathogenetic hypothesis of a hypothalamic-hypophyseal deficiency, with possible direct effects of $\mathrm{CS}_{2}$ also at the gonadal level, has been advanced $(3$, $4,8,16)$. Further studies on people chronically exposed to $\mathrm{CS}_{2}$ have shown a reduction of serum thyroxine $(5,9)$. The decrease was explained as possibly due to a thyroid impairment, but it was still doubtful whether the damage was primarily at the thyroid level or secondary to hypothalamic-hypophyseal involvement. 
In rats $\mathrm{CS}_{2}$ was demonstrated to exert its activity on catecholamine metabolism, and an interference with the conversion of dopamine to norepinephrine by dopaminebeta-hydroxylase was suggested (17). Likewise tetraethyltiuram disulfide (TETD), which is known to release $\mathrm{CS}_{2}$ in the organism $(12,21)$, is a powerful inhibitor of dopamine-beta-hydroxylase (13) and acts through a mechanism which seems similar to that of $\mathrm{CS}_{2}$.

A considerable amount of the research carried out in recent years has demonstrated that catecholamines may be considered the main agents of the neural control of endocrine homeostasis in the central nervous system. Through monoaminergic neurons catecholamines act as central neurotransmitters which regulate the hypophyseal hormone secretion by either stimulating or inhibiting peptidergic neurons.

Fig. 1 outlines the mechanism which underlies thyroid hormone secretion. At the hypothalamic level the monoaminergic neuron, through the peptidergic neuron, stimulates the release of the thryothropin releasing hormone (TRH); this peptide is thought to be secreted intermittently into the pituitary portal circulation from median eminence axon terminals in response to a variety of stimuli. TRH acts therefore at the hypophyseal level by stimulating the adenohypophysis basophilic cells to release the thyroid stimulating hormone (TSH), which in turn modulates thyroid activity through the synthesis and release of thyroxine and triiodothyronine. The secretion of other hypophyseal hormones and the functionality of the target glands appear to be regulated by a similar mechanism. It is therefore clear that a derangement of catecholamine metabolism may influence the activity of endocrine glands to a great extent.

The aims of our study were the following: (a) to study the effect of an acute administration of TETD, a substance which inhibits the transformation of dopamine into norepinephrine with a mechanism similar to that of $\mathrm{CS}_{2}$, on the mechanism of central endocrine regulation; (b) to determine which hypophyseal hormones are concerned with the pharmacological derangement of catecholamine metabolism; (c) to investigate whether the reduction of serum thyroxine, previously demonstrated in people chronically exposed to $\mathbf{C S}_{2}$, could be related to interference with catecholamine metabolism in the central nervous system.

\section{MATERIAL AND METHODS}

Sixteen voluntary medical students, nine males and seven females, who had previously given their informed consent,

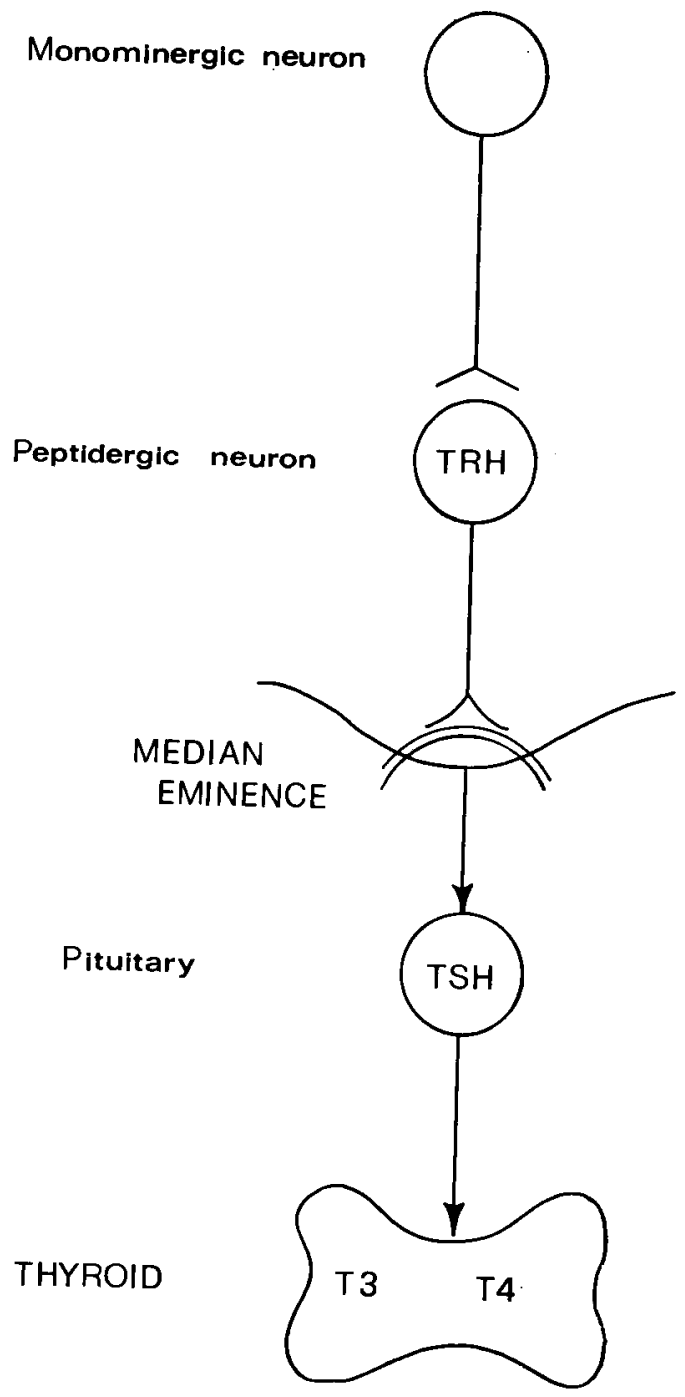

Fig. 1. Scheme of the hypothalamic-hypophyseal control of thyroid hormone secretion. 
were given $1.0 \mathrm{~g}$ of TETD (Antabuse, Dumex, Denmark) orally at 0800 . They were about $24-26$ years old, and their body weight ranged between 62 and $74 \mathrm{~kg}$ for the males and between 48 and $60 \mathrm{~kg}$ for the females. The volunteers were included in the experiment after their health status had been checked by a review of their medical history and a physical examination.

Blood samples were taken immediately before and at intervals of $1,2,4$ and $24 \mathrm{~h}$ after the medication. A parallel procedure was carried out with six males and five females who were matched with the experimental subjects with respect to age and body weight but who did not receive any drug.

Serum hormones were measured by radioimmunoassays with double antibody methods. For TSH the method of Odell et al. (25) was used, and the first I.R.P. TSH (WHO 68/38) was adopted as the reference standard. The sensitivity of the method is $0.5 \mu \mathrm{U} / \mathrm{ml}$. For prolactin the Sinha et al. (27) method was followed, and the standard was calibrated against international standard WHO 71/222. The sensitivity is of $1.5 \mathrm{ng} / \mathrm{ml}$.

Serum follicle-stimulating hormone and luteinizing hormone were assayed accord- ing to the Midgley methods $(22,23)$, and the standard preparations used were radioimmunologically calibrated against the second IRP - hMG and the LER 907. The sensitivity for both methods is $1 \mathrm{mIU} / \mathrm{ml}$.

For the comparison between the treated subjects and the controls statistical analysis was performed with Student's $t$ test, and the matched-pair $t$ test was used for the evaluation of the values found at the different hours in comparison with the base ones.

\section{RESULTS}

As shown in fig. 2, TETD induced a prompt significant reduction of TSH serum levels already $1 \mathrm{~h}$ after administration. In the later blood samples the reduction appeared to increase progressively and to reach the lowest level after $24 \mathrm{~h}$. The reduction pattern was practically the same in both sexes. In fig. 2 the results obtained in the control group are also illustrated; no significant differences from the base values were found at any time. When we compared the results obtained for the subjects administered TETD with those of the controls, we found highly significant. lower

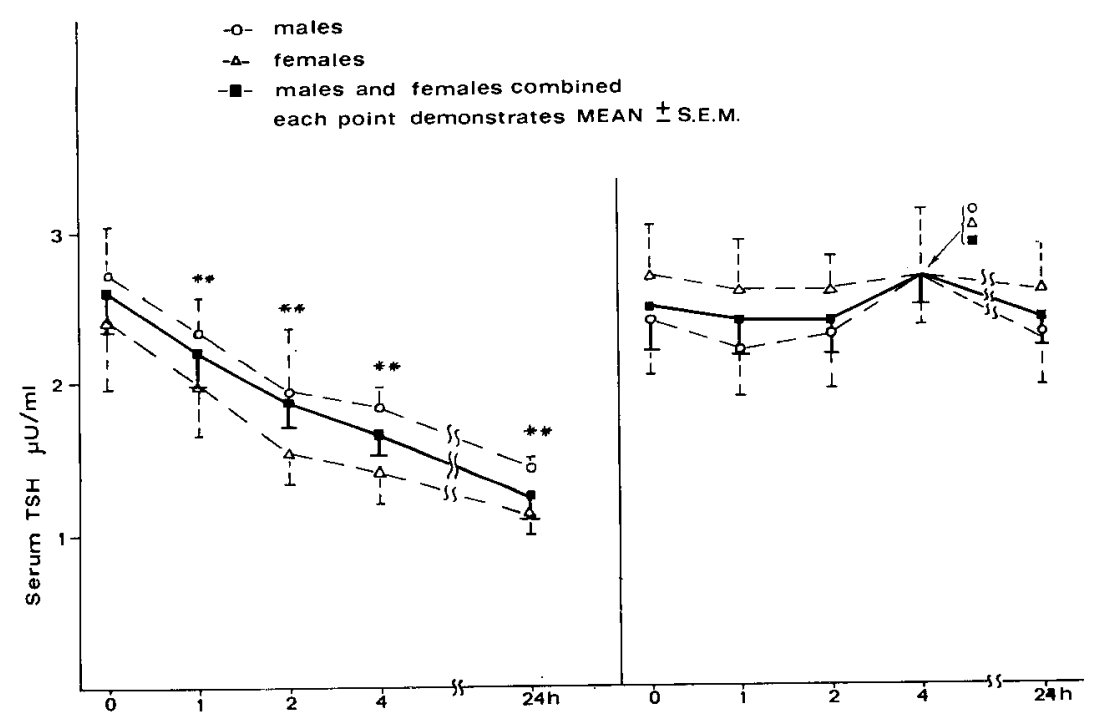

Fig. 2. Serum levels of serum thyrotropin in subjects administered tetraethyltiuram disulfide (left panel) and in the controls (right panel) $(* * \mathrm{P}<0.01)$. 


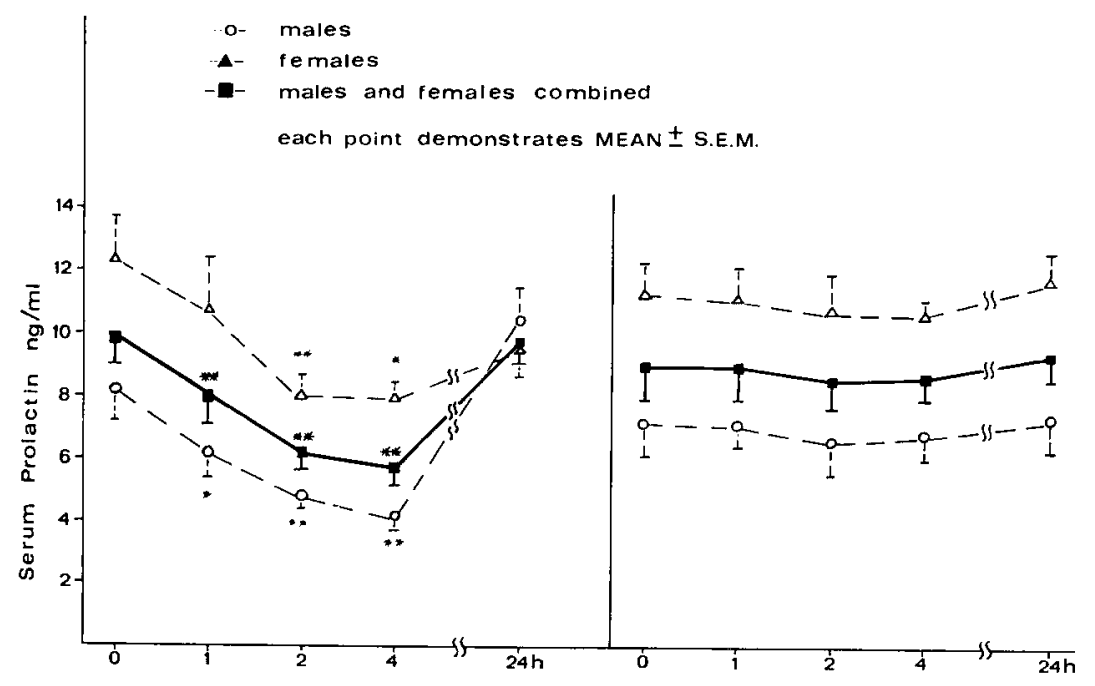

Fig. 3. Serum levels of prolactin in subjects administered tetraethyltiuram disulfide (left panel) and in the controls (right panel) $\left({ }^{*} \mathrm{P}<0.05 ; * * \mathrm{P}<0.01\right)$.

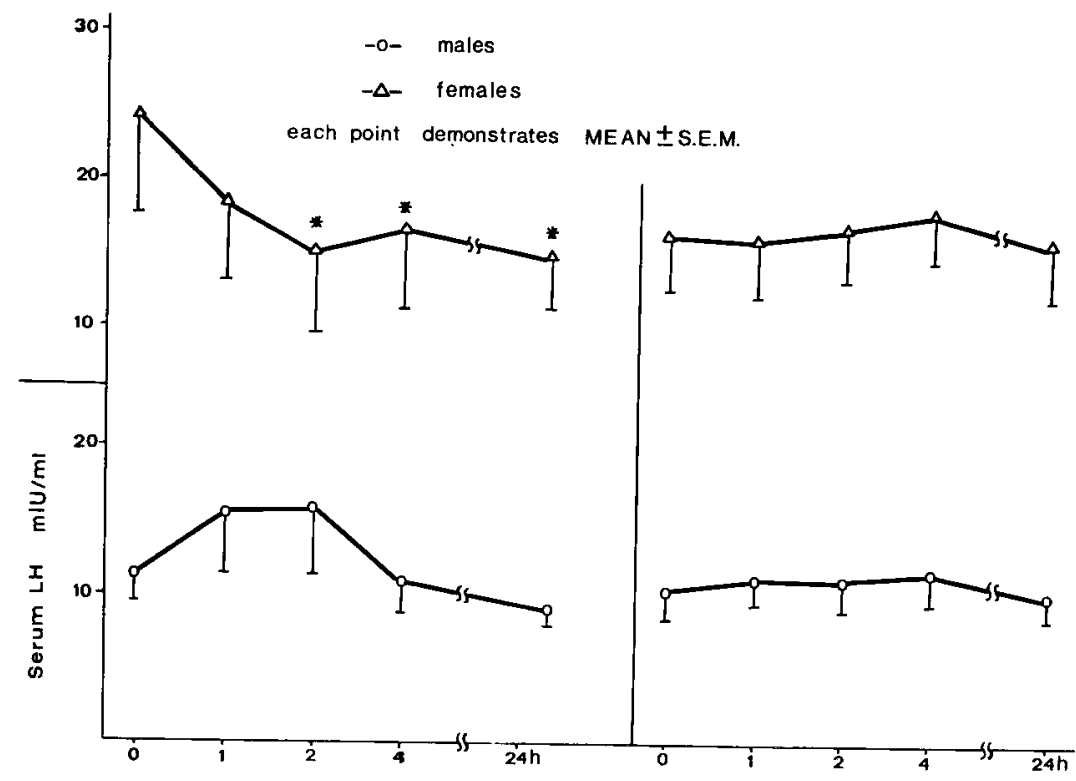

Fig. 4. Serum levels of luteinizing hormone in subjects administered tetraethyltiuram disulfide (left panel) and in the controls (right panel) $\left({ }^{*} \mathrm{P}<0.05\right)$.

values in the former group at the 4 th and the 24th $h(P<0.001)$.

Fig. 3 illustrates the effect of TETD on serum prolactin. As for TSH the decrease appeared already highly significant at the 1st $h(P<0.005)$, and the minimum was reached at the 4 th $h(P<0.001)$. After $24 \mathrm{~h}$, however, the base level was again reached. Also in this case the pattern was similar in both sexes. In the control group no significant variation was found for the various blood samples. In comparison with the controls, the treated group showed a significantly lower prolactin level at the 2nd $(\mathrm{P}<0.05)$ and 4th $(\mathrm{P}<0.005) \mathrm{h}$.

The level of luteinizing hormone did not 


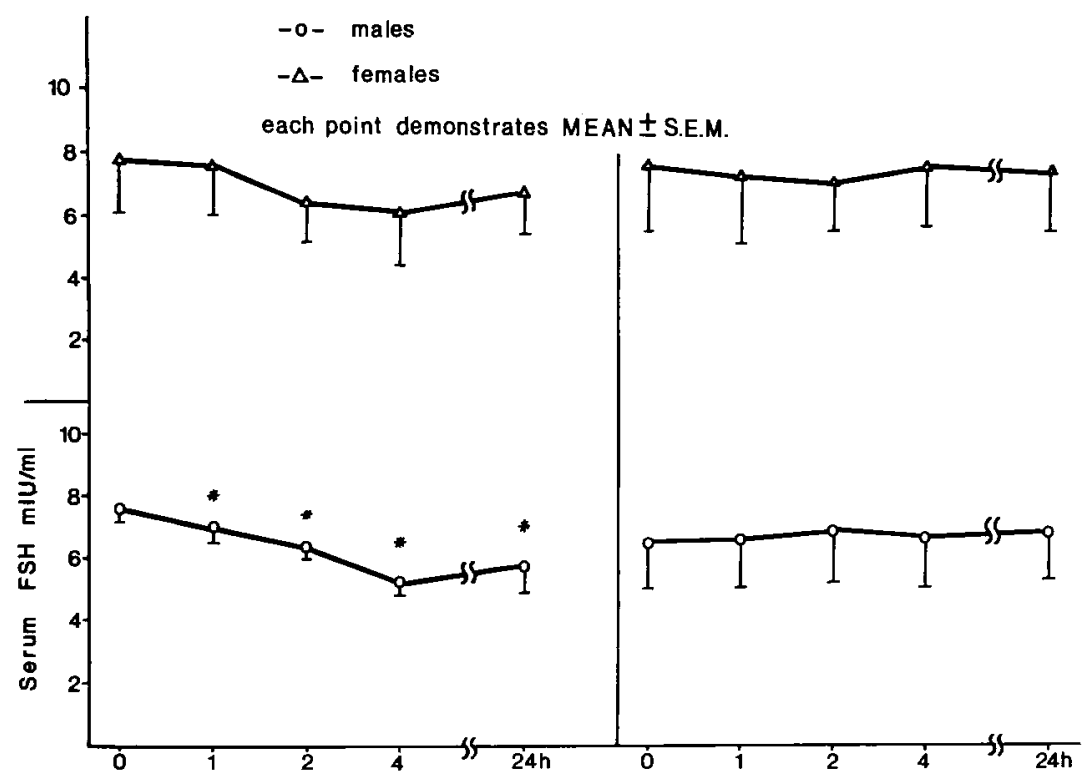

Fig. 5. Serum levels of follicle-stimulating hormone in subjects administered tetraethyltiuram disulfide (left panel) and in the controls (right panel) $(* \mathrm{P}<0.05)$.

vary significantly in the males, while the difference from the base value was statistically significant for the females at the 2nd $(\mathrm{P}<0.05)$ and 4 th $(\mathrm{P}<0.05) \mathrm{h}$ (fig. 4).

The reduction of follicle-stimulating hormone, not significant in the females, proved significant for the males at the 1st ( $\mathrm{P}<0.05)$, 2nd $(\mathrm{P}<0.05), 4$ th $(\mathrm{P}<0.005)$ and 24th $(\mathrm{P}<0.05) \mathrm{h}$ (fig. 5).

No significant variations in luteinizing hormone and follicle-stimulating hormone were found in the controls throughout the experiment. In comparison with the treated subjects no significant differences were found either for the males or for the females.

The results seem contradictory as to the significant reduction found for luteinizing hormone and follicle-stimulating hormone in females and in males, respectively, but they may be possibly explained by consideration of the small dimension of the samples investigated.

\section{DISCUSSION}

In our subjects acute administration of TETD induced a reduction of prolactin and TSH in serum, the former effect disappearing within $24 \mathrm{~h}$ and the latter persisting during the entire duration of the experiment.

It is known that an intravenous infusion of dopamine reduces prolactin and TSH significantly (1) and that bromocryptine, a dopaminerigc agent, markedly reduces both prolactin (11) and TSH (24). Hence it can be hypothesized that TETD provokes the reduction of the two hormones through the inhibition of dopamine-beta-hydroxylase and a consequent increase in brain dopamine, likely responsible for the effect demonstrated. Furthermore, the luteinizing hormone reduction induced by TETD may be related to a diminuation of the synthetized norepinephrine, even if in a less sharp way than in the case of TSH and prolactin.

The observed lower significance of the reduction of the serum levels of folliclestimulating hormone and luteinizing hormone could be explained on the basis of 
an incomplete blockade of norepinephrine synthesis, and, in such a case, chronic administration could induce a constant impairment in gonadotropin release. These results seem to tally with the lower luteinizing hormone and testosterone urinary excretion observed in $\mathrm{CS}_{2}$ exposed people.

Some conclusions can be based on the preceding findings.

TETD seems to induce in man a severe disturbance of cerebral catecholamine metabolism, which influences the secretion and release of hypophyseal hormones. If one accepts the fact that $\mathrm{CS}_{2}$ acts through a similar mechanism, the data obtained seem to agree with the theory that $\mathrm{CS}_{2}$ exerts its effects primarily at the level of the cerebral catecholamines $(17,18)$. These effects may provide an explanation for the endocrine system impairment demonstrated in people chronically exposed to $\mathrm{CS}_{2}$ by referring them to an impairment of the hypothalamic-hypophyseal function.

The reduced level of thyroxine in serum seems, in particular, to be ascribable to such a mechanism and not to a direct effect on the thyroid gland.

Furthermore, since it has been supposed that both TETD $(13,14)$ and $\mathrm{CS}_{2}(18,20)$ inhibit dopamine-beta-hydroxylase which is a copper enzyme - through copper chelation, at this state of knowledge it seems possible to unify the theory of metal chelation, the catecholamine metabolism disturbances, the involvement of endocrine function and, perhaps, the $\mathrm{CS}_{2}$ induced vascular damage into a common pathogenetic mechanism.

It should be recalled that fibrinolytic activity, which is likely to be related to the development of thromboembolic diseases and, therefore, to coronary heart diseases, is reduced in chronic $\mathrm{CS}_{2}$ exposure $(2,26,28)$. Now it is well known that epinephrine increases blood fibrinolytic activity (15), and a decrease in this catecholamine by TETD or $\mathrm{CS}_{2}$, because of their blocking effect on dopamine-beta-hydroxylase, could be involved in the reduction of fibrinolytic processes. Moreover, a disturbance in catecholamine metabolism could play a part in the hypertension sometimes evidenced in $\mathrm{CS}_{2}$ exposed people and in the increase of vascular resistances in the central area, which in turn would explain the raised opthalmic pressure found in exposed and intoxicated subjects (19).

\section{REFERENCES}

1. BESSES, G. S., BURROW, G. N., SPAULDING, S. W. and DONABEDIAN, R. K. Dopamine infusion acutely inhibits the TSH and prolactin response to TRH. J. clin. endocrinol. metab. 41 (1975) 985-988.

2. CANDURA, F., CRAVERI, A. and STRANEO, G. Contributo clinico allo studio dei rapporti tra arteriosclerosi e solfocarbonismo. Tromboelastogramma e fibrinolisi in soggetti normali, arteriosclerotici e solfocarbonisti. Folia med. (Naples) 65 (1972) $749-769$.

3. CAVALLERI, A. Rilievi endocrini nel solfocarbonismo. II. La funzionalità gonadica. Lav. um. 17 (1965) 416-423.

4. CAVALLERI, A. Rilievi endocrini nel solfocarbonismo. III. L'escrezione urinaria di androsterone ed etiocolanolone dopo stimolazione con gonadotropina corionica nel solfocarbonismo cronico. Lav. um. 18 (1966) $126-132$.

5. CAVALLERI, A. Serum thyroxine in the early diagnosis of carbon disulphide poisoning. Arch. environ. health 30 (1975) 85-
87 .

6. CAVALLERI, A., DJURIC, D., MAUGERI, U., BRANKOVIC, E., VISCONTI, E. and REZMAN, I. Endocrinological findings in young workers exposed to carbon disulphide: I. Urinary excretion of total 17-ketosteroids. Med. lav. 57 (1966) 566-572.

7. CAVALLERI, A., DJURIC, D., VISCONTI, E., REZMAN, I., MAUGERI, U. and BRANKOVIC, D. Endocrinological findings in young workers exposed to carbon disulphide. II. Urinary excretion of 17-hydroxycorticosteroids. Med. lav. 57 (1966) 573578.

8. CAVALLERI, A., MAUGERI, U. and VISCONTI, E. L'excrétion urinaire de téstostérone et de gonadotrophine stimulant les cellules interstitielles (ICSH) chez des sujets exposés au sulfure de carbone. Arch. mal. prof. med. trav. sec. soc. 31 (1970) 2230.

9. CAVALleri, A., TACCOLA, A., GRAOVAC-LEPOSAVIC, L., MAUGERI, U. and DJURIC, D. The serum thyroxine and the Achilles-tendon reflex in workers exposed to carbon disulphide. Med. lav. 62 (1971) $412-415$.

10. CAVALLERI, A. and ZUCCATO, F. Rilievi endocrini nel solfocarbonismo. I. La funzionalità gonadica. Folia med. (Naples) 48 (1965) $519-527$.

11. DEL POZO, E., BRUN DEL RE, R., VARGA, L and FRIESEN, $H$. The inhibition of prolactin secretion in man by CB-154 (2Br-a-ergocryptine). J. clin. endocrinol. metab. 35 (1972) 768-771. 
12. DJURIC, D. Some aspects of antabuse, carbon disulphide and ethyl alcohol metabolism. Arh. hig. rada 22 (1971) 171-177.

13. GOLDSTEIN, M., ANAGNOSTE, B., LAUBER, E. and MC KEREGHAN, M. R. Inhibition of dopamine- $\beta$-hydroxylase by disulfiram. Life sci. 3 (19.64) $763-767$.

14. GOLDSTEIN, M., LAUBER, E. and MCKEREGHAN, M. R. Studies on the purification and characterization of 3,4-dihydroxyphenylethylamine- $\beta$-hydroxylase. $J$. biol. chem. 240 (1965) 2066-2072.

15. KAULLA, K. N. Chemistry of thrombolysis: Human fibrinolytic enzymes. Charles C. Thomas, Springfield, Ill. 1963.

16. LANCRANJAN, I., POPESCU, H. I. and KLEPSCH, I. Changes of the gonadic function in chronic carbon disulphide poisoning. Med. lav. 60 (1969) 566-571.

17. MAGOS, L. Toxicity of carbon disulphide. Ann. occup. hyg. 15 (1972) 303-309.

18. MAGOS, L. The clinical and experimental aspects of carbon disulphide intoxication. Rev. environ. health 2 (1975) 65-80.

19. MAUGERI, U., CAVALLERI, A. and VISCONTI, E. Ophthalmodynamographic study in young workers exposed to carbon disulphide. In H. BRIEGER and J. TEISINGER (eds.), Toxicology of carbon disulphide. Excerpta Medica Foundation, Amsterdam 1967, pp. 150-152.

20. MC KENNA, M. J. and DI STEFANO, V. A proposed mechanism of the action of carbon disulphide on dopamine- $\beta$-hydroxylase. Toxicol. appl. pharmacol. 33 (1975) 137.

21. MERLEVEDE, E. and CASIER, H. Teneur en sulfure de carbone de l'air expiré chez des personnes normales ou sous l'influence de l'alcool ethylique au cours du traitement par l'Antabuse (Disulfiram) et le diéthyldithiocarbamate de soude. Arch. int. pharmacodyn. ther. 132 (1961) 427-453.

22. MIDGLEY, A. R. Radioimmunoassay: A method for human chorionic gonadotropin and human luteinizing hormone. Endocrinology 79 (1966) 10-18.

23. MIDGLEY, A. R. Radioimmunoassay for human follicle-stimulating hormone. J. clin. endocrinol. metab. 27 (1967) 295-299.

24. MIYAI, K., ONISHI, T., HOSAKAWA, M., ISHIBASHI, $K$. and KUMAHARA, $Y$. Inhibition of thyrotropin and prolactin secretions in primary hypothyroidism by $2-\mathrm{Br}$ $\alpha$-ergocryptine. $J$. clin. endocrinol. metab. 39 (1974) $391-394$.

25. ODELL, W. D., WILBER, J. F. and PAUL, W. E. Radioimmunoassays of thyrotropin in human serum. $J$. clin. endocrinol. metab. 25 (1965) $1179-1188$.

26. SAITA, G., SBERTOLI, C., FARINA, G. and GALLI, T. Azione del solfuro di carbonio sulla fibrinolisi. Med. lav. 53 (1963) $473-485$.

27. SINHA, Y. N., SELBY, F. W., LEWIS, U. J. and VANDERLAAN, W. P. A homologous radioimmunoassay for human prolactin. $J$. clin. endrocrinol. metab. 36 (1973) 509-516.

28. VISCONTI, E., VIDAKOVIC, A., CAVALLERI, A., REZMAN, I., MAUGERI, U. and VISNJIC, V. Fibrinolytic activity in young workers exposed to carbon disulphide. In: H. BRIEGER and J. TEISINGER (eds.), Toxicology of carbon disulphide. Excerpta Medica Foundation, Amsterdam 1967, pp. $128-132$.

Received for publication: 18 July 1977 